\title{
Cytomegalovirus IgG Antibody Measurement
}

National Cancer Institute

\section{Source}

National Cancer Institute. Cytomegalovirus Ig G Antibody Measurement. NCI Thesaurus. Code C96596.

The determination of the amount of cytomegalovirus IgG antibody present in a sample. 